\title{
Effect of Key User Empowerment, Purchasing Strategy, Process Integration, Production System to Operational Performance
}

\author{
Zeplin Jiwa Husada Tarigan ${ }^{1, *}$, Hotlan Siagian ${ }^{1}$, Sautma Ronni Basana ${ }^{2}$, and Ferry $\mathrm{Jie}^{3}$ \\ ${ }^{1}$ Master of Management Department, Faculty of Business and Economics, Petra Christian University, \\ Jl. Siwalankerto No.121-131,Surabaya, 60236, Indonesia \\ ${ }^{2}$ Financial Management, Faculty of Business and Economics, Petra Christian University, \\ Jl. Siwalankerto No.121-131, Surabaya, 60236, Indonesia \\ ${ }^{3}$ School of Business and Law, Edith Cowan University, 270 Joondalup Drive Joondalup WA, 6027, \\ Australia.
}

\begin{abstract}
This study examines the influence of key user empowerment on the operational performance through the mediating role of process integration, purchasing strategy and production system. The questionnaires were distributed to 120 manufacturing companies domiciled in East Java Region. Of the 120, 70 questionnaires are valid for further analysis. Data analysis used Partial Least Square (PLS) version 3.0. The finding are as follows: Key user empowerment affects the process integration. Key user empowerment influence the purchasing strategy. Process integration affects the purchasing. Process integration also influence the production system. Purchasing strategy provide support in the company's production system. Process Integration affects the company's operational performance. Purchasing strategy does not affect the operational performance. Purchasing strategy has an impact on company performance through a production system. The production system provides an increase in company performance. In summary, the key user empowerment has a direct and indirect impact on operational performance through process integration, purchasing strategy, and the production system. This study enriches the current research in supply chain management and provide an insight for the manager in improving the operational performance.
\end{abstract}

Keywords: Manager competency, organization performance, procurement, production planning and control.

\section{Introduction}

Changes in the global industry have resulted in a change in the majority of the world including the region of East Java, Indonesia. This globalization has also affected the business competitiveness of the country around the world. Since the competition is intensifying, and the country should improve their performance in all dimension such as quality, productivity, efficiency, and services. The manufacturing industry is one of the

\footnotetext{
${ }^{*}$ Corresponding author: zeplin@peter.petra.ac.id
} 
most affected by globalization changes. As understood, manufacturing company manage the transformation of raw material into finished products, and then distributing it to consumers. The most efficient manufacturing will champion the competition and come out as the winner. Therefore, the manufacturing companies have to seek the way how to achieve excellent performance in the pursuit of outperforming their competitor. One of the manufacturing industry which faces the constraint due to global changes are those manufacturing which is labor intensive such as manufacturing of furniture, consumer goods, household appliances, textile companies, electronic companies, garment companies. These companies have a problem of inefficiency compared to those who have used high technology in the production process. Another constraint facing the manufacturing company in East Java, Indonesia is the production cost which is relatively higher than neighbor countries such as Malaysia and Singapore. The main reason is the fact that lot number of manufacturing companies in Indonesia are primary Industry which used natural resources [1]. Primary industries are industries that rely on their raw materials mainly from natural resources. Actually, some manufacturing companies in East Java have applied high technology such as ERP into the planning and production process but, they have not achieved an optimal benefit for the company and the question of how to improve the operating performance of the company in the region of East Java Indonesia remains a challenging question for the researcher. From supply chain management perspective, many studies have been conducted to find out the way of improving the operational performance of an organization. The competition is intensifying in several dimensions such as quality, human resources competency, and a shortage of capital injected for research and development. Research conducted by Silalahi [2] stated that industrial systems in Indonesia require infrastructure support consisting of hard infrastructure and soft infrastructure. Today's globalization demands the manufacturing companies to have the infrastructure that is very critical in improving the capability up to the level of international standards and the use of industrial information systems such as industrial operational systems, industrial development and innovation, and development on the potential new market share. Besides that, manufacturing companies in Indonesia also need to make labor regulations that are flexible enough to provide space for companies to grow without the need to worry about being burdened by employee salary costs. Domestic industry in Indonesia must improve their performance in the pursue of outperforming the competitors.

All enterprises should strive to increase the performance which can be achieved through several factors such as providing the data visibility and system integration in the factories. They also need to integrate the data into the company's operations so that it can run the production process properly through an integrated information system. Many Manufacturing companies in East Java, Indonesia, actually, have used the Enterprise Resources Planning (ERP) system to improve the efficiency and effectiveness of the company's work. ERP can integrate all functions including marketing functions, logistic functions, distribution functions, purchasing functions, human resource functions, production functions, finance functions to improve efficiency and productivity (3-5).

However, this integration between these functions needs to be maintained and controlled which is normally by an assigned key user. Otherwise, the system will not work correctly in the long run. Key users are assigned by the company management to take the responsibility such as changing ERP module functions according to requirement, setting up the procedure and the assigning the people who enter data into the ERP system, adding programs as required by their functions, providing continuous training to enable the end ERP users, and integrating data retrieved from other functions. The role of the key user is highly critical for the success of the entire ERP system. As a result, all the key user from each function within the company are appropriately connected and integrated. Hence, the presence of the key users within the company must be continually developed and 
adequately empowered by the management. The empowerment means that the management delegate the responsibility and authority to the key user to make decisions concerning the enhancement of the ERP module as required by all the functions. Han \& Patterson [6] stated that the usage of information technology in integrating the process within the company has an impact on improving company performance. The application of easy-tounderstand information technology can provide accurate information regarding the company data in term of inventory of finished good, the raw material from suppliers. This shared information is expected to enhance the productivity of the company. The Empowerment also authorizes the key users to maintain the integration of the data between departments in the pursuit of data availability using the ERP.

Another factor that improves the operating performance is the purchasing strategy implemented by the company. The purchasing strategy determines how the relationship between the seller and purchaser is arranged. The primary goals of the purchasing strategy are to achieve the maximum mutual benefit for both sides. Purchasing department procures material for production needs must be able to meet the specifications set. In another word, purchasing strategy supports the production system of the company. This function, however, can not be appropriately implemented if the data required are not available at the right time. Among the information required by the purchaser are material identification, inventory, material specifications, material cost, and the approved suppliers. The use of information technology in integrating the process enables the purchaser to acquire this information. Also, the synchronization between functions in the company is increasingly integrated, more accessible, and more complete. Alignment of information obtained by the function of the purchasing department will be able to support the company's production system. The accurate procurement of raw materials and supporting materials provides smooth production. Subsequently, the smooth production process will improve the operational performance of the company.

Based on the above description, this research investigates the impact of key user empowerment on the operational performance through the mediating role of process integration, purchasing strategy and production system.

\section{Theoretical Review}

Operational performance is a result of the production system in manufacturing companies. The company's production system determines the extent to which the organization organizes all activities covering main activities and supporting activities in the course of achieving the planned operational performance. As described previously, the production system required the support from key user empowerment, process integration, and purchasing strategy.

\subsection{Operational performance}

Operational performance is measured as the extent to which the organization performs in the term of order fulfillment such as delivery speed, delivery reliability and flexible to change [7, 8]. How to improve the organization performance has become a concern of researcher so far. Research conducted by Madanhire and Mbohwa [9] states that ERP is capable of enhancing the efficiency in the term material usage, energy, inventory control, defect elimination, waste reduction, labor control and control of the production process. ERP is an application that can help organizations control their business better because it can reduce inventory level, increase stock turn over, reduce cycle time orders, increase productivity, better communication and have an impact on increasing company benefits. 
Operationally, ERP serves the companies to enhance the operational performance in term of reduction in lead-time, timely delivery, better customer satisfaction, better supplier performance, increased flexibility, and better use of resources.

\subsection{Production System}

The production system is a series of activities within the company to transform raw materials into finished products that have added value. The company's production system starts from the stage of receiving orders from customers that are converted into sales orders in the marketing function into the planning production function with product design. Making planning production in manufacturing companies using ERP implementation in companies is done by setting a master production schedule. At the stage of making the master production schedule, specific work plans are set to meet customer demand. The second stage creates a bill of material which is related to material specifications, material quantity, and the number of each item needed for each product. The third stage by paying attention to the accuracy of records in the warehouse section to find out the available finished product stocks and knowing available material items. Given those data available, the information system, ERP, can determine the raw material and supporting material requirements and the order quantity. Once the material requirement has been ordered and ready, the production system will run smoothly without any interruption. Subsequently, the production process must be monitored and controlled continuously to ensure that there is no deviation in term of quality and quantity from the planned target. This study measure the the the production system to indicate the extent to that the production is integrated with the master production schedule, implement the master production scheduled automatically by the ERP system, the master production schedule is integrated with the bill of material $(\mathrm{BOM})$, the company's inventory system is updated ERP systemically, and production controls are well run.

\subsection{Purchasing strategy}

Procurement is an essential activity to support the production process. Purchasing department should take care in selecting the suppliers to make sure that the company obtains the benefit in term of cost and production system operation. The company should build a partnership with a supplier in the pursuit of improving the competitive advantage. An appropriate Procurement provides an excellent opportunity to reduce company costs and hence increases the margins. For that goal, the company needs an appropriate purchasing strategy because of material composite the most substantial part of the production cost. Its membership in a long-term relationship is therefore expected to function as a partner, transmitting technical expertise and stable quality of production to manufacturing companies. Other researchers propose that purchasing strategy assess the extent to which the company establishes a partnership with the supplier [10-12]. Based on this research, the purchasing strategy is measured using four indicators which is i) builds good partnerships with suppliers, ii) partnership can determine the accuracy of material specifications at purchase, iii) purchasing strategy reflects market conditions, iv) purchasing strategy is part of the company's strategy.

\subsection{Process integration}


The integration of process in manufacturing companies is equivalent to data integration between functions within the company. Liu \& $\mathrm{Hu}$ [13] states that the system integration between departments is a cross-functional link within the company which jointly use an information technology application. This cross-functional partnership will share among the team member the skills and expertise in managing information technology to make accurate decisions. Xiao et al., [14] stated that systems integration could assist management in making accurate decisions which are needed to build competitiveness. Process integration between departments within the organization can provide work convenience for managers because it can reduce conflict and become a facilitator of communication. Process integration can reduce conflicts that occur between marketing departments and logistics and have an impact on improving business performance [15]. Research conducted by Gimenez [16] states that there are three stages of the integration process in the company. First, the existing data on the company is only integrated into the department; there is no integration between functions within the company. The second stage, the integration between functions within the company includes the integration function between the logistics and marketing of the company. The third stage, is the highest process integration, namely the integration in the company's functions and the integration with the company's external functions in the supply chain relationship. Indicators used to measure variables are data information between departments complete, accurate data integration, data integration between departments relevance and integration of data between departments on time.

\subsection{Key user empowerment}

The company resources such as human resources determine the competitive advantage of an organization. One of the human resources capitalizations is the empowerment of the employee in doing the responsibility and making a decision. The superiority of the employee such as a key user of the IT system plays a significant role in enhancing the competitiveness of the company. The key user mostly determines the success ERP implementation in companies. For this reason, the company needs to maintain and improve the ability and expertise of key users in line with the increasingly challenging expertise. Development of key users in the company can be done by giving adequate authority and responsibility in completing tasks and decision making. However, the granting of the authority requires a high awareness from the leaders when delegating the duties and responsibilities. Developing the ability of key users is highly required so that the ERP implementation and development process runs in properly [17, 18]. Key user empowerment assesses the extent to which the management has empowered the key user which is measured by five indicators, i.e., i) the key user is given clear authority, ii) the key user is given clear responsibility, iii) the key user is given adequate training, iv) the key user is prepared as a leaders, and v) between key users there is a good collaboration.

\subsection{Research concept framework}

The company competitiveness can be built by enhancing the company performance. The performance can be measured in term of financial and non-financial. A non-financial performance usually called an operational performance regarding efficiency, effectiveness, and productivity. The achievement of operational performance is highly supported by the production system which controls the transformation of raw material into finished products. An excellent production system provides an effective process and efficient usage of resources in the value-added production into a finished product. The production system supported by an integrated information system enable the department to monitor and 
control, at the right time, the predetermined schedule, product design, preparation and setting up of machinery for production, and material requirement. Provision of the information about the material requirement enables the warehouse to prepare and deliver the material to the production department directly. The system integration in the company is also beneficial for the purchasing department in making material because it is easy to know the user's wishes and product specifications needed by the user. System integration in companies using ERP technology that runs continuously and is maintained and developed by key users. A key user is a key person assigned by company management to ensure the ERP system runs and develops according to the company's external changes and customizes the ERP system accordingly with changes that occur within the company. The conceptual research framework can be built as follows:

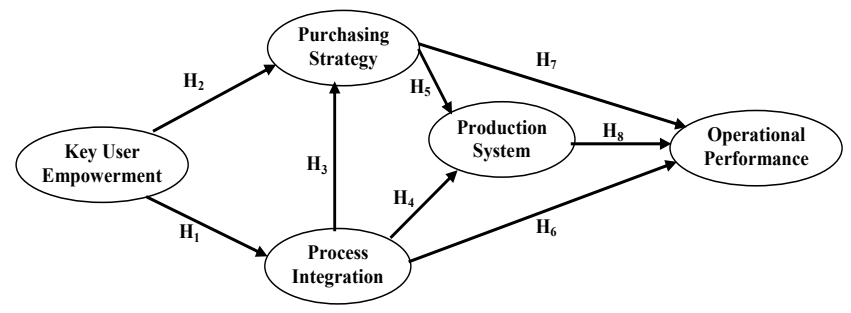

Fig. 1. Research conceptual framework

Based on the description above and Figure 1, eight hypotheses are proposed as follow:

H1: Key user empowerment influence the process integration

H2: Key user empowerment affects the purchasing strategy

H3: Process integration affects the purchasing strategy.

H4: Process integration influence the production system

H5: Purchasing strategy affects on the production system

H6: Process integration affects operational performance

H7: Purchasing strategy improve operational performance.

H8: Production system influence the operational perfor-mance.

\section{Research Methods}

The population of this study includes the manufacturing companies domiciled in the region of East Java Indonesia mainly located in the industrial area. The data collection used questionnaires and distributed the assigned respondent. Data collection at the initial stage is done by visiting the company 38 questionnaires were distributed. This initially collected data are used to test the validity and the reliability of the instrument before the second are conducted. The results of the initial test found that the value of the corrected item-total correlation greater than 0.3 which means all indicators are valid and the instrument can be used to collect the data as the second stage. From the reliability test, the result of the analysis indicated that those five variables have reliability more significant than 0.70 (recommended minimum value). Those five variable key user empowerment, process integration, purchasing strategy, production system, and operational performance have the value of reliability respectively equal to $0.795,0.887,0.904,0.742,0.831$. The second stage, then, was performed by distributing the questionnaires to the rest of the manufacturing companies as many as 82 companies. The distribution of the questionnaires 
was carried out with the assistance from the student of the master management. Of the 82 , 50 questionnaires returned and complete. The rest were missing and incomplete data. The total number of questionnaires distributed during the first and second stage were 120 questionnaires, and 70 questionnaires were valid. The response rate is $58.3 \%$ which is still acceptable for the research in the management study.

\section{Analysis and discussion}

The researchers have distributed the questionnaires as many as possible to the ERP key users in the company. These ERP key users in companies generally have a management position such as manager, assistant manager, head of the department, staff officer, senior staff, and supervisor. The distribution of the respondents based on the position is shown in Table 1 .

Table 1. Key user position

\begin{tabular}{lll}
\hline Position & Number & Percentage \\
\hline Top Management & 22 & $28.21 \%$ \\
Manager & 40 & $51.28 \%$ \\
Asisten Manager & 8 & $10.26 . \%$ \\
Supervisor & 2 & $2.56 \%$ \\
Officer & 1 & $1.28 \%$ \\
Senior Staff & 5 & $6.41 \%$ \\
\hline Total & 78 & $100 \%$ \\
\hline
\end{tabular}

Majority of the respondents have the position as a manager followed by the Top management, Assistant Manager, Senior staff, supervisor and officers. This composition indicates that those respondent have a responsibility in the organization structure. Hence they are knowledgeable in the company policy decision making and strategy, and at the same time, they are responsible for the development and customization of the ERP system in his department. The respondents are also involved in the company budget allocation which means they can allocate the fund for the development of the information technology requirement.

Table 2. The key user education grade

\begin{tabular}{lcc}
\hline \multicolumn{1}{c}{ Education } & Number & Percentage \\
\hline Doctoral & 1 & $1.28 \%$ \\
Master & 25 & $32.05 \%$ \\
Bachelor & 47 & $60.26 \%$ \\
Diploma & 3 & $3.85 \%$ \\
High school & 2 & $2.56 \%$ \\
\hline Grand Total & 78 & $100 \%$ \\
\hline
\end{tabular}

Table 2 indicates the education level of each respondent. The education level of the respondent showed that majority of the respondents are well educated which means that they can understand the questionnaires and they can fill in the questions in the questionnaire.

The manufacturing involved in this study have used the ERP system, and the producer of the software consists of several producers as listed in Table 3. However, there are 35 companies which developpes their software. This Table 3 indicated that all respondents had 
applied ERP system into their organization process. The main reason for developing their software is the cost which highly expensive to purchase the software.

Table 3. ERP software used

\begin{tabular}{lll}
\hline ERP software & Number & Percentage \\
\hline Self-developed software & 35 & $44.87 \%$ \\
SAP & 31 & $39.74 \%$ \\
Oracle & 9 & $11.54 \%$ \\
People Soft & 2 & $2.56 \%$ \\
MFG PRO & 1 & $1.29 \%$ \\
\hline Grand Total & 78 & $100 \%$ \\
\hline
\end{tabular}

The hypothesis testing is conducted in two stages using the partial least square (PLS) version 3.00. The first stage assesses the validity and reliability of the measurement model. The validity assesses if the indicators of each variable are correlated with its variable which is determined by the factor loading (convergent validity) of the indicator with a minimum recommended value of 0.5 . The second validity measurement is the cross loading (discriminant validity) of the indicator which measures if the correlation of each indicator with its variable is higher than its correlation with other variables. The reliability of the variables is measured using the Cronbach alpha and composite reliability. Table 4, demonstrated the result of the validity measurement. All indicators are valid in term of convergent validity since all the factor loading are higher than 0.5 (range from 0.50 up to 0.838). Similarly, those indicators are valid in term of discriminant validity since all indicators have cross loading lower than its factor loading.

Another assessment for the measurement model is the reliability of each variable. In this study, the reliability is measured using the composite reliability and the Cronbach Alpa. The minimum acceptable reliability for both measurements is 0.6 . Table 6 listed the value of reliability for each variable. As seen on the Table 6 , all variables are considered reliable since all reliability value are greater than 0.6 (all cases range from 0.625 up to 0.880 ). Based on this result, the measurement model of this study is considered valid and reliable. The value of R-Square is another measurement which assesses the variance of the operational performance. The higher the R-Square value, the higher the percentage of variance of the operational performance explained by the model (19). As shown in Table 5, $\mathrm{R}$-square for the operational performance is 0.426 , which means that $42.6 \%$ of the variance in the operational performance is explained by the variance of the other four variables. The predictive relevance $\left(\mathrm{Q}^{2}\right)$ is another measurement for the inner model. The predictive relevance indicates the ability of the model to predict the operational performance. Based on the Formula (1), predictive relevance denoted as follow:

$$
\mathrm{Q}^{2}=1-\left(1-\mathrm{R}_{1}^{2}\right)\left(1-\mathrm{R}_{2}^{2}\right)\left(1-\mathrm{R}_{3}{ }^{2}\right)
$$

Where:

$\mathrm{Q}$ : predictive relevance

$\mathrm{R}^{2}$ : the variance of dependent variable explained by the independent variable.

The value of the $\mathrm{Q}^{2}$ found equal to 0.921 (much greater than 0.00 ), and it means the model has an excellent predictive relevant. 
Table 4. Loading factor and cross loading of the indicators

\begin{tabular}{llllll}
\hline Indicators & $\begin{array}{l}\text { Key user } \\
\text { empowerment }\end{array}$ & $\begin{array}{l}\text { Operational } \\
\text { performance }\end{array}$ & $\begin{array}{l}\text { Process } \\
\text { integration }\end{array}$ & $\begin{array}{l}\text { Production } \\
\text { system }\end{array}$ & $\begin{array}{l}\text { Purchasing } \\
\text { strategy }\end{array}$ \\
\hline X.1.1. & $\mathbf{0 . 6 5 2}$ & 0.236 & 0.519 & 0.312 & 0.396 \\
X.1.2. & $\mathbf{0 . 7 5 3}$ & 0.316 & 0.303 & 0.506 & 0.593 \\
X.1.3. & $\mathbf{0 . 7 8 7}$ & 0.271 & 0.417 & 0.338 & 0.606 \\
X.1.4. & $\mathbf{0 . 7 4 5}$ & 0.303 & 0.311 & 0.383 & 0.505 \\
X.1.5. & $\mathbf{0 . 7 9 0}$ & 0.287 & 0.507 & 0.463 & 0.606 \\
X.2.1. & 0.256 & 0.241 & $\mathbf{0 . 5 4 5}$ & 0.332 & 0.318 \\
X.2.2. & 0.223 & 0.305 & $\mathbf{0 . 6 6 3}$ & 0.325 & 0.237 \\
X.2.3. & 0.345 & 0.401 & $\mathbf{0 . 6 8 9}$ & 0.358 & 0.374 \\
X.2.4. & 0.555 & 0.47 & $\mathbf{0 . 7 9 0}$ & 0.545 & 0.712 \\
X.3.1. & 0.592 & 0.263 & 0.42 & 0.538 & $\mathbf{0 . 7 9 1}$ \\
X.3.2. & 0.597 & 0.343 & 0.665 & 0.428 & $\mathbf{0 . 7 9 1}$ \\
X.3.3. & 0.481 & 0.355 & 0.541 & 0.522 & $\mathbf{0 . 7 9 9}$ \\
X.3.4. & 0.674 & 0.336 & 0.535 & 0.546 & $\mathbf{0 . 8 3 8}$ \\
X.4.1 & 0.445 & 0.404 & 0.436 & $\mathbf{0 . 6 9 6}$ & 0.473 \\
X.4.2. & 0.492 & 0.397 & 0.404 & $\mathbf{0 . 5 6 6}$ & 0.441 \\
X.4.3. & 0.357 & 0.472 & 0.317 & $\mathbf{0 . 7 1 1}$ & 0.36 \\
X.4.4. & 0.158 & 0.253 & 0.435 & $\mathbf{0 . 5 8 3}$ & 0.389 \\
X.4.5. & 0.206 & 0.383 & 0.326 & $\mathbf{0 . 6 2 5}$ & 0.333 \\
X.5.1. & 0.193 & $\mathbf{0 . 5 0 0}$ & 0.142 & 0.24 & 0.218 \\
X.5.2. & 0.285 & $\mathbf{0 . 6 6 0}$ & 0.334 & 0.411 & 0.254 \\
X.5.3. & 0.107 & $\mathbf{0 . 5 9 4}$ & 0.305 & 0.375 & 0.168 \\
X.5.4. & 0.26 & $\mathbf{0 . 6 4 0}$ & 0.32 & 0.316 & 0.268 \\
X.5.5. & 0.117 & $\mathbf{0 . 5 7 1}$ & 0.32 & 0.359 & 0.16 \\
X.5.6. & 0.354 & $\mathbf{0 . 5 4 0}$ & 0.419 & 0.375 & 0.348 \\
\hline
\end{tabular}

Table 5. Reliability and R-square of variables

\begin{tabular}{|c|c|c|c|}
\hline Variables & $\begin{array}{l}\text { Cronbach's } \\
\text { Alpha }\end{array}$ & $\begin{array}{l}\text { Composite } \\
\text { Reliability }\end{array}$ & R-Square \\
\hline \multicolumn{2}{|c|}{ Key User Empowerment 0.801} & 0.863 & \\
\hline Operational Perform & 0.625 & 0.757 & 0.426 \\
\hline Process Integration & 0.625 & 0.769 & 0.309 \\
\hline Production System & 0.635 & 0.773 & 0.456 \\
\hline Purchasing Strategy & 0.819 & 0.880 & 0.637 \\
\hline
\end{tabular}

The next analysis is to test the hypotheses by assessing the inner model. The hypotheses testing is conducted by examining the path coefficient and t-value of each path coefficient. Table 6 listed the value of the path coefficient and the t-value respectively. This result demonstrated that those eight hypotheses are supported.

For the first hypothesis, it was found that the key user empowerment had an impact on the company's process integration with path coefficient 0 f 0.556 and $P$ value of 0.000 . Key user empowerment affects the company's process integration. The key user, having higher authority and broader responsibility, will be more capable of realizing the processes integration between departments to ensure the availability of data and the establishment of a cross-function between departments. This study supports the research by Wu and Wang [18] stating that key user empowerment has an impact on the implementation of ERP for the pursuit of data accuracy, reliability, responsiveness, and completeness. This research 
also the research of Huang [19] which states that key user behavior is important in implementing information technology to improve IT performance

Table 6. The result of hypotheses testing

\begin{tabular}{lcccc}
\hline \multicolumn{1}{c}{ Relationship } & $\begin{array}{c}\text { Original } \\
\text { Sample }(\mathrm{O})\end{array}$ & $\begin{array}{c}\text { Sample } \\
\text { Mean }(\mathrm{M})\end{array}$ & $\begin{array}{c}\text { Standard } \\
\text { Deviation }\end{array}$ & $\begin{array}{c}P \\
\text { Values }\end{array}$ \\
\hline Key User Empowerment -> Process Integration. & 0.556 & 0.580 & 0.065 & 0.000 \\
Key User Empowerment -> Purchasing Strategy & 0.516 & 0.509 & 0.082 & 0.000 \\
Process Integration -> Operational Performance & 0.346 & 0.354 & 0.119 & 0.004 \\
Process Integration -> Production System & 0.324 & 0.340 & 0.128 & 0.011 \\
Process Integration -> Purchasing Strategy & 0.386 & 0.389 & 0.078 & 0.000 \\
Production System -> Operational Performance. & 0.480 & 0.498 & 0.112 & 0.000 \\
Purchasing Strategy -> Operational Performance. & -0.132 & -0.140 & 0.152 & 0.385 \\
Purchasing Strategy -> Production System. & 0.413 & 0.406 & 0.115 & 0.000 \\
\hline
\end{tabular}

The second hypothesis which states that key user empowerment had an impact on the company's purchasing strategy is supported with the path coefficient of 0.516 and $P$-value of 0.000 . Key user empowerment has an impact on the company's purchasing strategy. The key user empowerment built by the company through a broad training for the key users to improve their competence and be able to collaborate well between departments. The key user of each department can identify demand orders that are reflected in the system so that each user can request the exact material specifications when making a purchase. This is consistent with research conducted by Chen [20] that purchasing strategy in companies is carried out by managers and directors as key person in the company using supply chain management in the company. This research is also in line with the research of Akdogan and Demirtas [21] which states that managers are key factors in the department in running the supply chain, in this case also managers are key people in improving company performance.

The third hypothesis, stating that process integration had an impact on the company's purchasing strategy is also supported with the path coefficient of 0.386 and $P$-value of 0.000. Process integration has a positive and significant impact on the company's purchasing strategy. When the process within the organization is all integrated, it will enable all departments to share the information. The purchasing department, supplied with data required, can make an appropriate decision making in determining the purchasing strategy. The purchasing department can retrieve the information regarding the material specification, material quantity, and the schedule of the production. This research is in line with the research by Ince et al. [22] stating that quality information provided by the ERP system has a positive impact on establishing a strategic partnership with suppliers.

Similarly, with the fourth hypothesis, the result indicated that process integration influences the company's production system with the path coefficient of 0.324 and $P$-value of 0.011 . Production system needs support from all main activities and the supporting activities such as process integration. Process integration including data integration makes sure that data such as the master production schedule, bill of materials, and product delivery are available at the right time. This research is in line with the research of Brunoe et al., [23] stating that information integration in manufacturing companies can improve the production process and product configuration. This research is in line with integrating production planning and maintenance with a distribution system to give an impact on the production system related to the system schedule

For the fifth hypothesis, it is found that the purchasing strategy has an impact on the company's production system obtained at 0.413 and $P$-value 0.000 less than 0.05 ; so the 
fifth hypothesis is acceptable. Purchasing strategies have a positive and significant impact on the company's production system. Data integration in the company enables one department to communicate with other departments regarding material specifications, master production schedule, bill of material (BOM) in supporting the production. This research is in line with Paiva's research [24] which states that the integration of data can have a positive and significant impact on operational performance.

For the sixth hypothesis, it is found that process integration has an impact on the company's operational performance as shown by the path coefficient of 0.346 and the $p$ value of 0.004 . This finding proves that Process integration is essential within the organization activities either main activities or supporting activities. In the end, this integration improves operational performance. Process integration is equivalent with data integration between departments which enables all department to retrieve the data in the right time according to their requirement. This finding is in line with Paiva's research [24] which states that data integration between marketing and production has a positive and significant impact on company performance. This research also supports the research by Ehm and Freitag [25] which states that the integration between production and transportation schedule can reduce lead times and storages times. This research is also in line with the research by Zhao et al. [26] that integrating production planning and maintenance has the potential to improve company performance, especially in increasing equipment utilization.

In contrary with previous hypotheses, the seventh hypotheses are not supported by this study. Purchasing strategy does not have an impact on the company's operational performance as shown by the path coefficient of -0.132 and $P$-value 0.385 (higher than 0.05). Purchasing strategy can determine the material specifications at the time of purchase and be able to reflect market conditions, but it does not directly impact the performance. Even though the purchasing strategy can procure the material as required, but it is not directly related to the performance because there is the subsequent stage of the process such as warehouse management, before the material delivered to the production process.

The last hypotheses of this state that the production system affects the company's operational performance. As shown by the analysis result, the path coefficient is 0.480 and $P$-value 0.000 . This finding implies that production systems have a positive and significant impact on the company's operational performance. The finding is reasonable because the production system determines the achievement of operational performance such as production cost and productivity. The order fulfillment should be integrated the master production schedule and the bill of materials (BOM) in order the company can precisely deliver the product based on the customer demand. This research is in line with the research of Neumann et al. [27] stating that the production system and production process design has an impact on improving company performance, especially on product quality. This research is in contrary to the study of Paiva's research [24] which states that operation priorities have no impact on company performance.

An additional finding from this research is the fact key user empowerment did not affect the operational performance through the purchasing strategy. The key user empowerment affects indirectly the operational performance through the process integration and the production system. Based on this result, the management of the company needs to consider empowering all the key user of the ERP and establish the process integration dan production system of better operating performance. 


\section{Conclusion}

The primary purpose of this study is to examine the influence of key user empowerment on the operational performance through the mediating role of the process integration, purchasing strategy and the production system. The result proves that one of the eight hypotheses is rejected and seven hypotheses are supported. The existence of a key user of ERP was highly strategic for the company to determine the sustainability of the ERP system. The empowerment is realized through adequate training and capability in building teamwork in collaborating with all key users. Key user empowerment will enhance the process integration, which at the end will indirectly influence the operational performance. The establishment of process integration enables a system updated and sharing of relevant data required by the related department. The process integration allows the purchasing department to identify the material and components needed by the company's production department. The purchasing department can use ERP to retrieve data regarding customer demand as represented on the master production schedule. The ERP provides material requirement in the form of bill of material (BOM). The empowerment of key users enhances the process integration, and the process integration affects the production system. The production system at the end improves the operational performance.

\section{References}

1. A. Jayadi, H.A. Aziz, J. Dev. Econ., 2 :12-27 (2017). https://ejournal.unair.ac.id/JDE/article/view/5119

2. S.A.F. Silalahi, Jurnal Ekonomi \& Kebijakan Publik, 5,1:1-13(2014). http://jurnal.dpr.go.id/index.php/ekp/article/view/149 [in Bahasa Indonesia].

3. V. Botta-Genoulaz, P.A. Millet, Int. J. Prod. Econ., 99(1-2):202-221 (2006). https://www.sciencedirect.com/science/article/pii/S0925527304004621

4. H.M. Beheshti, Manag. Res. News, 29(4):184-193(2006). https://www.emeraldinsight.com/doi/abs/10.1108/01409170610665040

5. Leon, A., Enterprise Resources Planning. McGraw-Hill Publishing Company Limited, New Delhi, 2005. https://books.google.co.id/books?id=s5YiBAAAQBAJ\&hl

6. X. Han, P. Patterson, Int. J. Ind. Ergon., 61:131-141(2017). https://www.sciencedirect.com/science/article/pii/S0169814117302731

7. B. K. Chae, C. Yang, D. Olson, C. Sheu, Decis. Support. Syst., 59:119-126(2014) https://www.sciencedirect.com/science/article/pii/S0167923613002595

8. Z.J.H. Tarigan, IJBS, 19,2:335-346(2018). http://www.ijbs.unimas.my/images/repository/pdf/Vol19-no2-paper6.pdf

9. I. Madanhire, C. Mbohwa, Procedia CIRP, 40:225-229(2016). https://www.sciencedirect.com/science/article/pii/S2212827116001232

10. A. Paulraj, I.J. Chen, J. Flynn, J. Purch. Supply Manag., 12,3:107-122(2006). https://www.sciencedirect.com/science/article/pii/S1478409206000653

11. C. Sánchez-Rodríguez, J. Bus. Ind. Mark., 24,3/4:161-172(2009). https://doi.org/10.1108/08858620910939714

12. L. Bildsten, Procedia Econ. Financ., 21:594-600(2015). https://www.sciencedirect.com/science/article/pii/S2212567115002178

13. J. Liu, C. Hu, Procedia Eng., 174:1182-1189(2017). https://doi.org/10.1016/j.proeng.2017.01.277

14. Y. Xiao, H. Zhang, T.M. Basadur, J. Bus. Res., 69,2:587-595(2016). https://www.sciencedirect.com/science/article/pii/S0148296315002258 
15. M.L. Pimenta, A.L. da Silva, W.L. Tate, Int. J. Logist. Manag., 27,2: 570-594(2016). https://www.emeraldinsight.com/doi/abs/10.1108/IJLM-01-2014-0010

16. C. Gimenez, Int. J. Phys. Distrib. Logist. Manag., 36,3:231-249(2006). https://www.emeraldinsight.com/doi/abs/10.1108/09600030610661813

17. W. Suprapto, Z.J.H. Tarigan, S.R. Basana, "The influence of ERP system to the company performance seen through innovation process, information quality, and information sharing as the intervening variables," in Proceedings of the 2017 International Conference on Education and Multimedia Technology, 2017, pp. 87-91.https://dl.acm.org/citation.cfm?id=3124131

18. J.-H. Wu, Y.-M. Wang, Comput. Human Behav., 23,3:1582-1596(2007). https://www.sciencedirect.com/science/article/pii/S0747563205000518

19. M. Huang, Procedia Eng., 29:1824-1829(2012). https://doi.org/10.1016/j.proeng.2012.01. 220

20. I.J. Chen, A. Paulraj, A.A. Lado, J. Oper. Manag., 22,5:505-523(2004). https://doi.org/10.1016/j.jom.2004.06.002

21. A.A. Akdogan, O. Demirtas, Procedia-Social Behav. Sci., 150:1020-1029(2014). https://www.sciencedirect.com/science/article/pii/S1877042814051635

22. H. Ince, S.Z. Imamoglu, H. Keskin, A. Akgun, M.N. Efe, Procedia-Social Behav. Sci., 99:1124-1133(2013). https://www.sciencedirect.com/science/article/pii/S1877042813040317

23. T.D. Brunoe, D.G.H. Sørensen, A.-L. Andersen, K. Nielsen, Procedia CIRP, 72:592597(2018). https://doi.org/10.1016/j.procir.2018.03.020

24. E.L. Paiva, Int. J. Prod. Econ., 126,2:379-386(2010). https://www.sciencedirect.com/science/article/pii/S0925527310001520

25. J. Ehm, M. Freitag, Procedia CIRP, 41:585-590(2016). https://doi.org/10.1016/j.procir.2015.12.143

26. S. Zhao, L. Wang, Y. Zheng, Ind. Manag. data Syst., 114,2:162-182(2014). https://www.emeraldinsight.com/doi/abs/10.1108/IMDS-07-2013-0314

27. W.P. Neumann, A. Kolus, R.W. Wells, IFAC-PapersOnLine, 49,12:1721-1724(2016). https://doi.org/10.1016/j.ifacol. 2016.07.830 